\title{
A Congolese Virus and Belgian Doctors? Postcolonial Perspectives on Migration and HIV ${ }^{1}$
}

\author{
Charlotte Pezeril ${ }^{\mathrm{a}}$ and Dany Kanyeba ${ }^{\mathrm{b}}$ \\ a) Researcher 'Observatoire du sida et des sexualités' \\ Saint-Louis University, Brussels, Belgium \\ charlotte.pezeril@yahoo.fr \\ b) Présidente Association Libiki, Brussels, Belgium \\ dkanyeba@yahoo.fr
}

\begin{abstract}
Based on collaborative research between a Congolese activist in HIV prevention in Belgium and a French anthropologist, this paper hopes to initiate a debate about the issue of HIV /AIDS in light of the postcolonial links between Belgium and its former colony Congo/Zaire. By exploring the social representations that HIV has generated in Francophone Belgium and the changing political management of the epidemic since the 1980s, the paper focuses on how Congolese HIVpositive migrants have been viewed, treated and allowed (or not) to settle in Belgium. It analyzes how the HIV/AIDS epidemic was seen as an 'African disease,' and more precisely a 'Congolese virus.' It concludes that Achille Mbembe's 'postcolonial scoriae' must be taken into account (without necessarily implying a linear passage from colonial to postcolonial relations) in order to understand European and international policies in Africa or policies concerning African migrants.
\end{abstract}

\section{Keywords}

postcolonial, HIV/AIDS, migration, race, bio-politics

\section{Résumé}

Fruit d'une collaboration entre une militante congolaise dans la prévention du VIH et une anthropologue française, cet article veut engager une réflexion sur les liens entre la Belgique et son ancienne colonie le Congo/ Zaïre, autour de la problématique du VIH/sida, à la fois sous l'angle des représentations que le sida a générées, mais aussi de la gestion politique de l'épidémie et de son évolution depuis les années 1980. Il analyse plus précisément comment les migrants congolais séropositifs ont été appréhendés, traités et autorisés (ou non) à s'installer en Belgique. Il montre comment l'épidémie de VIH/ sida va être essentialisée comme une "maladie africaine" en Belgique; légitimant ensuite l'instauration du dépistage obligatoire du VIH pour les étudiants.

1) We would like to extend our thanks to Sarah Demart and Myriam Dieleman for their critical reviews of this work and to the journal's anonymous reviewers for the care and precision of their remarks. We would also like to thank our translator, Joe Costanzo, for his helpful work. 
En conclusion, comme Achille Mbembe l'a théorisé, les "scories postcoloniales" doivent être prises en compte (sans que cela implique un passage linéaire du colonial au postcolonial) si nous voulons comprendre les politiques européennes et internationales aujourd'hui en Afrique ou à l'égard des migrants africains.

Mots-clés

postcolonial, VIH/sida, migration, race, biopolitique

La pensée postcoloniale insiste sur l'humanité-à-venir, celle qui doit naître une fois que les figures coloniales de l'inhumain et de la différence raciale auront été abolies.

- Achille Mbembe 2006: 118

\section{Introduction}

In this article, we would like to initiate a debate on the links between Belgium and its former colony, the Democratic Republic of the Congo (DRC), formerly Zaire, around the issue of HIV/AIDS, not only in terms of how AIDS has been represented in Belgium, but also the political management of the epidemic (Dodier 2003) and its evolution since the 1980s. If Bayart (2009) believes that "postcolonial studies deal less with practice than discourse and representations from which they expound" the approach taken here is almost the reverse.

On the one hand, following the theoretical perspective of Mbembe (2006, Bancel 2010), our goal here is to retrace our field data while trying to identify the "scories" or legacies left by colonial, imperial, and racial ideologies in the imaginary as well as in the concrete practices of those involved. The idea here is to assess the practical effects of dominant representations and yet, simultaneously, not be limited to them.

On the other hand, the idea was not initially to track "postcolonial thinking" as to how Congolese migrants living with HIV are understood in Belgium, but instead to thoroughly examine the research data and field evidence of the particular link to the colonial relations between the two countries. There is some reluctance on our part to take any one approach, especially any particularly French approaches (which often overstate the postcolonial argument, as sometimes they are too inclusive and also disconnected from a historical and contextual foundation and one which ultimately overestimates colonialism). ${ }^{2}$

2) See Roitman, 2011 and the complete work of Public Culture dedicated to "Racial France," issue 63, Winter 2011, 23/1. 
Therefore, there was no question in our research of a presupposed historical and linear continuity with colonisation, much less a ready-made, monocausal, and mechanical link with all the experiences and practices of Congolese migrants in Belgium. Nevertheless, and despite Francophone reluctance, we must question the racialized social relations even if race does not exist as such - as it has been amply demonstrated since the Second World War - it is still significant as an imaginary and discriminating category in our societies, especially when added to a person's weakened state of health. As Dieleman's analysis (2008: 22) suggests, "As for the 'sickly migrant', he doubly threatens his identity since, the otherness of his 'race' is superimposed onto the otherness of his 'disease."

We will therefore pay particular attention in this paper to avoid, on the one hand, reducing the postcolonial perspective to the study of postcolonialism and its impacts (Roitman 2011), insofar as such a perspective attempts to deconstruct prejudices preceding it (including slavery). On the other hand, we will do our best not to "reify or essentialise the legacies and memories, while underestimating the dialectic of social movement and contemporary production of discrimination" (Cahen 2011: 906). Cahen specifies correctly that the postcolonial goes beyond colonisation, both as a historical period and as an approach to "go beyond the ruins" (2011: 904). As characterized by Mbembe (2006), postcolonial thinking (even if it cannot be convincingly used in the singular) is one of entanglement. Neither thinking of the past or anti-European thinking, it is at the crossroads between the past and the present, between the elsewhere and the here. We shall see that it is also not an idea of face-to-face meetings between former colonizers/formerly colonized, since it crosses globalization and racial imaginary beyond national borders.

However, it is necessary to clarify upfront that the French debates are not identical to those in Belgium, which has neither the same colonial history (recall that until 1908, the Congo was originally the private property of the King) nor France's republican ideals (Belgium is a kingdom), nor even the same political structure (Belgian federalism involves a co-existence of different policies toward foreign and foreign-origin populations between Flanders and Wallonia; see Jacobs \& Rea 2005), even if the French-speaking part of the country - the focus of this article - is influenced by these debates and follows the French universalist model of color-blindness. ${ }^{3}$

3) France has chosen a universalist, color-blind (or "race-neutral") model to dominate public policy making. For example, unlike the UK, France does not represent race in its national statistics. 
In addition, the postcolonial question is recent in the French-speaking Belgian academic world. ${ }^{4}$ Even as it emerges at the end of the 1990 s as a review of the colonial past and of a "repentant Belgium"5 (Gillet 2007), the debate elicits little interest and remains confined to intellectuals and the politically savvy, and has little impact on the field of migration. For Jacquemin (2004: 253), "Trying to evoke the symbolic place occupied by Congolese humanity in the history of social thought and in the imagination of Belgians, invariably invokes images of a minor presence (présence mineure) and a mysterious disappearance (disparition mystérieuse)." Indeed, the settlement of the Congolese in Belgium was negligible up until decolonization (10 Congolese were counted in 1947; Kagné 2000), and migration was hardly encouraged (no bi-national agreements on labor migration, as was the case with Morocco) and finally limited under the Schengen Agreement. At the same time, the media remained silent on the participation of Congolese troops in the war effort and on all other Congolese contributions to Belgium (Kagné \& Martiniello 2001).

The history of AIDS in French-speaking Belgium, and particularly its emergence in the public sphere in 1983, is part of this legacy, revived and renewed in a single gesture. This article focuses on how HIV-positive Congolese migrants were arrested in Belgian public spaces, were cared for, and allowed (or not) to settle in Belgium; and not on how the DRC managed the epidemic, ${ }^{6}$ although this is certainly of great interest for understanding the Belgian colonization of the Congo. We intend this work to be a way of starting a discussion and reflection; it is therefore by no means exhaustive. At the outset of this article, we describe how AIDS was identified as an African, and more specifically, Zairian disease. Second, we analyze the change in public policy that led to both the invisibility of African migrants living with HIV, to their control by medical surveillance and, in some cases, even their removal. Finally, we revisit the stories of Congolese activists in the fight against AIDS in Belgium to assess the persistence of the practice of HIV testing upon entry and the difficulties facing community-based organizations, despite their protests and the concretization of European humanitarian and anti-discrimination law.

This research is based on a collaboration between a Congolese activist in HIV prevention in Belgium, a coordinator of the association Libiki charged

\footnotetext{
4) See (among others) issues of journals like La Revue Nouvelle, $\mathrm{n}^{\mathrm{o}}$ 1-2, January 2005 and $\mathrm{n}^{\circ} 7$, July 2010 and Politique, $\mathrm{n}^{\circ}$ 65, June 2010.

5) In 2000, Prime Minister Guy Verhofstad recognized the responsibility of the Belgian State in the Rwandan tragedy, and in 2002 Minister Louis Michel apologized to the Congolese people and the Lumumba family. See in particular Gillet (2007).

6) In this case, we refer specifically to Fassin (1994) and Gruénais (1994).
} 
with the support, monitoring, and advocacy for those infected with and affected by HIV/AIDS and a French anthropologist working since 2008 in the Brussels-based Observatory for AIDS and Sexuality (l'Observatoire du sida et des sexualités, Brussels) on issues of stigma and discrimination against people living with HIV in Belgium. The data presented here comes from both observation of and participation in activities involving actors in AIDS prevention in Francophone Belgium, documentary research (press releases, organizational archives, laws and regulations, inventory of media campaigns, etc.), interviews, ${ }^{7}$ and a quantitative survey on the living conditions of people living with HIV in the Wallonia-Brussels Federation (formerly known as the French Community). ${ }^{8}$

\section{3-1986: A Zairian Virus?}

In French-speaking Belgium, AIDS appeared on the political agenda in 1983, two years after France and the United States. This time lag is important, not only to grasp and understand the epidemic, but to describe and specify its potential "victims," who form the so-called "risk groups" of the disease. While Americans popularized the " $4 \mathrm{H}$ " (Homosexuals, Haitians, Heroin addicts, and Haemophiliacs) and France's Libération entitled it the "gay cancer,"9 Le Soir, one of the most important newspapers in French-speaking Belgium, called AIDS “African," "indigenous," or "imported." ${ }^{10}$ In 1983, we could read in their columns:

New and serious disease, the homosexual syndrome barely threatens Belgium. At first, it almost seemed like a joke. You'd think, 'a disease that only affects homosexuals!' (...) For us [in Belgium], about twenty cases have been reported, ten of which have already resulted in a fatality. These were all Africans, mainly from Zaire who came here to be treated. $(05 \cdot 20.83)$.

7) Unless otherwise noted, the interviews were face to face and non-directive and conducted by C. Pezeril in French. Averaging over two hours each, approximately 30 interviews were conducted with professionals (both current and past) working in the "AIDS sector" in the WalloniaBrussels Federation.

8) Begun in 2008 by GRECOS (Reflection group on communication and seropositivity), this study comes from a collaboration between the Platform for AIDS Prevention, the Observatory of AIDS and Sexuality and the Centre for Sociological Studies (Université de St. Louis, Brussels). Preliminary results were published in late 2012. See Pezeril 2012.

9) Libération, no 619, 17/05/83.

10) See in particular Le Soir of 19/o6/86 or of o8/12/86. 
The designation as "endangered Africans" - which doubles both for public health (as a source of contamination) and finance (as a health insurance liability) $)^{11}$ - supports the image of a relatively protected "general population" (read white and heterosexual). "A.I.D.S. would not be contagious vis-à-vis the general population" claimed the press (Le Soir, 07/22/83). The Minister of Health for the French Community, André Bertouille, even established a clear link between the African epidemic, so-called therapeutic immigration and the Belgian epidemic:

Belgium is the European country with the highest incidence of AIDS. In fact, the real significance of this statistic is distorted by the large number of non-resident aliens from Central Africa who come to seek care in our country. (as cited in Dieleman 2008: 23)

However, from 1984-85, with early epidemiological monitoring, the ratio Belgian-to-foreigner was balanced with regard to HIV diagnoses (but not for reported AIDS cases), ${ }^{12}$ the number of foreign nationals not surpassing Belgian nationals until 1988 (Dieleman 2008: 15) when HIV-positive foreigners became invisible within the broader public space.

Unlike France, where invisibility or denial was early and persistent (Fassin 1999; Musso 2009; Cervera \& Hourcade 2010), "Africans” are immediately identified and recognized as one of the first "risk groups" of the epidemic in Belgium (Hubert 1990; Dieleman 2008) at least in its French-speaking part. ${ }^{13}$ Especially migrants from Zaire or "Central Africa" are targeted - meaning those former colonies of the Congo/Zaire, Rwanda, and Burundi (so-called Trust territories after the First World War), though, according to different definitions, Central Africa can include a dozen or so countries.

The first to claim this epidemiological uniqueness were physicians, infectious disease specialists, biologists, and generalists who, on one hand, saw patients from Zaire and on the other, had close ties with medical teams in Zaire and in the sub-region. Antwerp's Institute of Tropical Medicine - which was created during colonization - houses the works of Peter Piot (a microbiologist), who coordinated the first international project (Congolese-Belgian-

\footnotetext{
11) Most of them are eligible for care.

12) The nationality is known for about 70 percent of those diagnosed. To be precise, before 1985 , 275 Belgians and 263 non-Belgians were identified as HIV positive. The figures for AIDS cases are hard to find but reports indicate an unbalanced ratio (almost three-fourths of non-Belgians). See Sasse A, et al. 2005.

13) Not able to be fully developed here, it would seem that Flanders understood AIDS as a gay virus during the 1980s. One of the reasons to explain this is perhaps because the settlement of Congolese migrants took place mainly in Brussels and Wallonia.
} 
American) on AIDS in Kinshasa in 1984, and became one of the figures in the fight against AIDS in Belgium and in the world (he led UNAIDS from its inception in 1995 to 2008). In Brussels, the team of Nathan Clumeck (an infectious disease specialist) saw the first patients and created a major multidisciplinary service center dedicated to AIDS in the country (CETIM at the Saint-Pierre hospital). Clumeck also published its research and spoke regularly in the Francophone media, where he was introduced as "the" AIDS expert. Finally, we should mention Dr. Jean-Louis Lamboray, founder of Bel Compétence and of DRC Compétence (organizations working to develop the "process of AIDS competency"), which began in Zaire in $1973 .{ }^{14} \mathrm{He}$ was later appointed to the World Bank, then to the UN project on AIDS (a position from which he resigned in 2004). These three emblematic figures were quite familiar with Zaire, having worked directly with local teams. They were not alone, as one of our interlocutors within the AIDS sector in Belgium told us, "almost everyone working in HIV worked in Congo/Zaire," whether they be doctors, politicians, anthropologists, etc., which explains, in part, the focus around an "African AIDS."

The first scientific paper by Clumeck's team published in The Lancet in 1983 was entitled "Acquired immunodeficiency syndrome in Black Africans" (Clumeck et al. 1983). He reported 20 or so "Black African" patients who developed the symptoms of AIDS and, surprisingly for the time, self-identified as heterosexual, not drug addicts, or haemophiliacs, and including women. Meanwhile, the Kinshasa team tried to publish similar results in the New England Journal of Medicine but were rejected. According to Vangroenweghe, "the editors could not believe that AIDS was a heterosexual disease. They insisted that the team must have neglected to consider one or another mode of transmission or some rare African custom" (Vangroenweghe 2000: 89). It wasn't until one year later than the Lancet would publish the findings of the Piot team, after various modifications, under the title: "Acquired immunodeficiency syndrome in a heterosexual population in Zaire" (Piot et al. 1984).

The possibility of heterosexual transmission was far from being recognized by scientists, which explains why the interest in African cohorts was obvious. Lise Thiry, another figure in the fight against AIDS, and virologist at the Pasteur Institute, says that a meeting held in 1983 to explain the virus turned sour:

I remember well there were mostly Congolese students in Belgium, especially at the University of Liège. And so I was invited to the University of Liège, for a conference with the goal of

14) Appointed by the Belgian Cooperation in Disele hospital, he was responsible for organizing the network of free clinics that revolved around this Fomulac hospital, the Medical Foundation of the University of Lovanium in the Congo. See Le Journal du médecin, No. 1868 - 23.10.2007. 
smoothing things out, appease the Congolese students who were furious with us for being said to be disgusting, unclean and that they had an awful disease. These were all things like that. (...) They forced me from the stage; I could not stay. Ah yes, because they said I was being dishonest, I was... And they told me that I was discriminating against them. But I did not discriminate against them. And also at that time, we really didn't know. (Interview, 24/07/2009)

On the one hand, doctors tended to inform the Congolese of a specific risk; on the other hand, this reinforced racial discrimination, even if doctors did not intend to do so. This anecdote reminds us of the conflict between the medical and epidemiological perspectives, which emphasizes the over-representation of Zairians or more broadly Africans among AIDS patients in Belgium, and the militant perspective which focused on human rights which emphasized the violence produced by the imagination of this "Zairian virus" and the racism that presided and flowed from it. These vivid reactions are better understood by making a short detour to the Congo/Zaire.

\section{AIDS of the Other ${ }^{15}$}

Meanwhile in the Congo, one of the first countries to adopt specific structures to combat the disease, ${ }^{16}$ AIDS was constructed as "a public policy problem without becoming a political issue nor one debated in public discourse" (Fassin 1994: 748). The only debate that appeared in the Congolese press concerned the alleged African origin of the virus. ${ }^{17}$ The coverage "challenges the assertion of this [African] identity claim and denounces it as racism easily accepted by the authorities" (Fassin: 757). Conversely, the absence of AIDS as a topic from the public sphere in the Congo can be explained by the fact that "the management is beyond the Congolese political world, not only because it was made out to be a strictly medical problem, but also because solutions could only come from elsewhere" (Fassin: 759). Thus, "AIDS immediately took on a meaning within the web of relations between the West and Africa" (Dozon 2005: 211) and gave rise to either forms of denial or of accusations which, aimed

\footnotetext{
15) See the title "Le Sida des autres," exciting issue of Autrepart ( $\mathrm{n}^{\circ}$ 12) edited by Claude Fay, 1999.

16) Since 1985, a Scientific Committee of diagnosis and prevention was created, and in 1987 , launched the National Programme against AIDS.

17) This point can unfortunately not be developed here, but deserves further analysis from a postcolonial perspective. The question of the origin of the virus unleashed a heated debate, following the discovery of a sample of infected blood dating back to the 1950 in Zaire. See Fassin \& Dozon 1989, Bibeau 1991.
} 
at the West, pronounced that HIV was inseparable from its imperialist enterprises or that it resulted from experiences or vaccination campaigns ${ }^{18}$ conducted by the pharmaceutical industry from the North (Nkuku Khonde 2006).

Congo and Belgium have both constructed the "AIDS of the Other," except that the parties were not on an equal footing. On the one hand, the Congolese representations were soon de-legitimized by the West and assimilated as "false beliefs" or referred to as a former colonial resentment or a way of not taking responsibility. On the other hand, Western explanations of the African endemic would take decades before their culturalist even racist bases were denounced - citing the "unbridled sexuality" of Africans and their inability to change their behavior (because they are too attached to their "roots" and "traditions") (Fassin \& Dozon 1989; Bibeau 1991; Hunsmann 2010). These dynamics are impossible to understand without taking into account the racial and colonial history. Bibeau (1991) shows how articles in scientific journals, which drew on clichés and stereotypes, helped to invent an Africa that probably existed only in Western fantasy through their unsubstantiated thesis of the virus' African origin and based on the conceptualization of a caricatured and distinct homo sexualis africanus, omitting the economic and social contexts to explain the African epidemic. This re-created the image of a primitive or "doomed" Africa, prone to indolence and pleasure.

These representations explain why AIDS remained absent from the public area, except in terms of "accusation." Dozon and Fassin stress wisely: "This reluctance, hostility or even irony expressed by doctors and African politicians is not surprising, vis-à-vis the AIDS problem" (1989: 25). The authors mention that the first symposium on AIDS in Africa, held in Brussels in 1985, was boycotted by African doctors. In this context, it is important to remember that Zairian doctors were actively involved in research and not out of step with their European colleagues. Some of the results of Zairian researchers were internationally hotly debated. An example of this is the work by Professor Zirimwagabado Lurhuma, Head of the Department of Immunology (Faculty of Medicine in Kinshasa), and by Dr. Shafik in Egypt, which led to the announcement in 1987 of the development of a drug against AIDS - called MM1 (for Mobutu and Mubarak) - which however turned out to be disappointing. His mysterious

18) Belgium was even suspected of having played a vital role in the production of the AIDS virus itself in its colonial laboratories in the Congo. See the controversial thesis that the virus was accidentally created by scientists testing an experimental oral polio vaccine in the 1950s: see Hooper E., 1999 . 
disappearance was ascribed to Western pharmaceutical lobbies or by the CIA, of which this testimony by an HIV-positive Congolese migrant is illustrative:

I would say that when it started, a good twenty years ago, it was clearly the 'syndrome invented to discourage lovers'. And then all of us, men and women alike, me, I am 50 years old, but the generations marked by the sexual liberation of May 68, and all that, is different from an Islamic Malian society, and where freedom of speech is less than it is here. I would say that Kinshasa is a city where freedom of speech is great. Between men and between women alike, between men and women, more than you might think. I think it is in the Congo where there was first talk of AIDS. From the beginning of AIDS, and, curiously, we have often said in the Congo: 'No, it is a disease created in a laboratory from the improper handling by Americans.' Because in those years, in the very moment when AIDS appeared, there was a split between the Congolese government and the U.S. government's medical cooperation ... a tumultuous split. There was really, almost overnight, at the hospital Mayebo, we sought out the American medical cooperation. Shortly after, the director of the American hospital, who was there on this research project in the general hospital of the city of Kinshasa, becomes the director of the UN AIDS project. So really, overnight! And the young Congolese doctor named in the Congo as managing director of the AIDS disease was assassinated, dying in a staged accident. Who killed him? Is it the CIA because in fact, we claim that 'Americans were in the process of experimenting on something in this hospital.' (...) And one day, in $84-85$, I think, doctor Lurhuma appeared on television, he was the researcher at our university in medicine who was announcing that he had found the drug to cure AIDS. So we are told it with great fanfare on television: 'Lurhuma discovered the drug against AIDS. Zaire is at the forefront of science', things like that. (...) And I think that going deeper, the situation is different here. I mean that we, as a community here, we are trying to discover something. But there, there is already a long history. And compared to this long history, there is different freedom of speech compared to here..$^{19}$

The richness of this interview excerpt underlines two important elements which, in different ways, further the conspiracy issues mentioned above. First, HIV-positive Zairian migrants coming to Belgium were not ignorant about AIDS, and it was not a taboo in the country of origin to speak about AIDS, at least not in some circles, especially in urban areas and in the private sphere, contrary to representations in Belgium. The interview excerpt furthermore undermines the common discourse which juxtaposes the sickly and ignorant Zairian with the sick but informed Belgian and the competent Belgian physician with the unknowing or less-qualified Zairian doctor. These dualities simply reinforced a European-centric perception of an impoverished Africa, despite the national programs and public information campaigns in the fight against AIDS which began in the same period, in 1987, in both countries (and both equally focused on the equation AIDS = death).

19) This interview was carried out in May 2006 in French within the scope of the research project "HIV and migration" of the Observatoire du sida et des sexualités (See Dieleman 2008). 
Second, the quote illustrates a wider view that AIDS was an invention of the Other related to the perception that its deadly consequences were deliberately orchestrated by "the West" on the Zairian people, including the assassination of the doctor who might have saved them. ${ }^{20}$ Does this representation, which entails an accusation of mass murder and assumes an international conspiracy, not reinstitute the rationale of the process of colonial elimination? Without suggesting that there is a direct link, the combined accusations seem to replay the colonial relations of stigma, power, and violence. The representation of AIDS as a Western invention to subjugate Africa emerges at the same time as the representation of AIDS as an African disease caused by sexual promiscuity (or exotic sexual practices as female vaginal drying practices, polygamous, or even levirate marriages) but one cured by civilized and competent nations (through research on the virus and in the care of the sick). Such a perspective can only be understood within the paradigm of colonial history and its developmentalist heritage (which goes beyond the strict BelgianCongolese relationship). In Belgium, this discourse helped to legitimize the idea of "AIDS of the Other" and, eventually, as we shall now see, built a mechanism for controlling the country's borders. On this point, AIDS merely restates the already long-established link between immigration, the infectious (or contagious) epidemic, and the control of and/or discrimination against foreigners. Several authors (historians and anthropologists studying health) have shown that the construction of a contagious disease, one inevitably originating from abroad, facilitates the shift in accusation: from the virus to its victims. ${ }^{21}$ The Other becomes the ideal culprit, easy to identify and to blame. The practice of designation and isolation are therefore completely justified.

\section{The Turning Point of 1986: Universalization of Risk and Mandatory Testing}

In 1986, after having focused on the "Zairian AIDS," public officials realized that AIDS also was affecting the Belgian population. French-language newspapers began speaking of a "domestic sickness" noting that "heterosexuals are increasingly infected" (La Libre Belgique, 06/27/86). The policy began shifting towards

\footnotetext{
20) Lurhuma himself supported this idea of the foreign-ness of AIDS, stating in Jeunes Afrique in 1986 that AIDS was introduced into the Congo by foreigners who had sexual relations with prostitutes, called "Londoners" ("londoniennes") (See Nkuku Khonde 2006).

21) Regarding HIV, see the excellent study by Paul Farmer (1996); but also Clatts \& Mutchler (1989), "On the analogy between AIDS and Syphilis," see Gilman (1988).
} 
a universalization of risk, at least in the public space. Clumeck interjected in the media repeatedly stating that AIDS "is not a disease of the other" (Le Soir, 10/22/86) and could happen to "Mr. and Mrs. Everybody." Faced with the risk of abuse and racist and/or homophobic reactions, the message adopted a generalist perspective, where everyone ought to be concerned about AIDS. According to Hubert (1990), the "duty to act" against AIDS had collided with the "political fear" of stigmatizing Africans, resulting in an invisibility of the initiatives taken on their behalf. All the while criticizing it, François Delor ${ }^{22}$ reused the French Republican prism to argue:

In a way, we have created from scratch the ideal of a Republican virus. That is to say, a virus that obeys a quasi-citizen logic from the revolutionary imperative 'Everyone is equal and brothers in solidarity before AIDS.' (Delor 1999)

However, the Belgian political management remained very ambiguous on this point, adopting a double discourse, generalist for the broad public, and specialized for the field through subsidizing thematic associations ${ }^{23}$ (Cantelli 2007). Indeed, since 1986, the French Community ${ }^{24}$ (in Belgium) has subsidized a position in the Immigrant Social Service Office (Service social des étrangers) responsible for analyzing the situation of African immigrants in relation to AIDS.

Included in this policy change was the decision to impose a test for HIV on certain categories of immigrants. These included students and applicants for a grant from the Belgian Administration for Development Cooperation (BADC) of which the majority came from Zaire. Thus, the invisibility of African migrants coincided with a policy of their control and supervision, as if the public denial of the problem allowed a stricter regulation on the ground. When this "case" broke, students made up a significant segment of the Zairian population in the Belgian territory on a long-term basis (Demart 2013). In February 1987, Le Soir revealed that 1,500 students (and their spouses), mostly African and in particular Zairian, were summoned by the government to pass a serological test.

\footnotetext{
22) Sociologist and founder of Ex cequo (Association for the prevention of AIDS among gays) and of Observatoire du sida et des sexualités. Delor died in 2002.

23) Populations considered of high priority in the middle of the 1980 included homosexuals, foreigners, drug addicts and prostitutes.

24) Recall that Belgium is divided into three Communities (French-speaking, Flemish and German-speaking) and three Regions (Brussels, Flanders and Wallonia). Here we do not discuss the institutional intricacies of the country, but more globally, the federal government is responsible for health care reimbursements (via the INAMI, the National Social Security Office), whereas the Regions subsidize the hospitals and prevention is managed at the Community level.
} 
Interviewed by the media, representatives from the State Secretariat of Public Health claimed no knowledge of this initiative while the Office of Cooperation (Cabinet de la Coopération) admitted wanting to take "an inventory" (Le Soir, 02/27/87). On March 3, the decision was endorsed by the Council of Ministers that any recipients of grant funding must undergo a medical examination, including an HIV test before their funding could be approved and could be allowed to stay in Belgium. Those refusing to submit to the test or found to be HIV + could have their scholarship and their permission to stay denied. During her time working for the Immigration Office (Service des étrangers), Maureen Louhenapessy, recalls:

Pretty quickly, there was a big problem with the BADC. The BADC, that was the Agency for Development Cooperation at that time, which asked the fellows, that was in 1987 , to take a screening test. So for that I had to organize conferences directly in Matonge ["Congolese" district of Brussels], because it was a little heated. Trying to have political contacts to understand why they wanted to screen African students, to go into the homes of African students. (...) And it was really almost a riot. Because most people did not understand what was going on. So I put together a whole series of information, of sessions. (Interview, 23/07/2009)

Students refused to take the test, and some human rights groups mobilized so that the HIV-positive students would not be sent back to their country of origin. Though the scandal appeared in the media only in 1987 , these practices had been suspected for some years beforehand (as early as July 1985). Peter Piot and Michel Caraël even denounced them in 1985 considering them as "serological screening" useless for controlling the epidemic (see Dossier Sida, CEDIF 1986). The Boards of Directors of the ULB and UCL (French-speaking Free University of Brussels and the Catholic University of Leuven, respectively) reacted against this measure calling it discriminatory and ineffective, and the new Ambassador of Zaire to Belgium, Mushobekwa Kalimba wa Katana, expressed his frustration:

In short, this test confuses dangerous HIV-positive people with those who are not. Regardless, the scholarship recipient who forfeits their scholarship will be traumatized for the rest of his/her life. Additionally, it is discriminatory to impose the test only on recipients from the Third World and not students from the United States or elsewhere. The goal is to protect the Belgian population against AIDS. Only a general measure is tolerable (Le Soir, 03/10/87).

The Council of Ministers of the African, Caribbean, and Pacific States for a time even considered retaliating against European visitors (Vincineau 1991: 765). Nevertheless, the Belgian Secretaries of State for Cooperation (André Kempinaire) and Public Health (Wivina Demeester) rejected all accusations 
of discrimination, arguing that Belgian overseas volunteer corps (coopérants) would also be tested, to which the students and their advocates countered that embassy staff and business people should be similarly tested (La Libre Belgique, 05/03/87). In April, Ms. Demeester could not hide the fact that this scandal was ad hoc and being secretly handled. She announced the withdrawal of the BADC measure, while specifying that fellowship candidates would still be tested prior to their scholarship application (i.e., before entering the territory), while HIV-positive students already in the territory "will be monitored and treated in Belgium." She justified her decision by saying: "There is a large community of people from Central Africa who maintain numerous interrelations with the Belgian population", ${ }^{25}$ reiterating the image of the "evil of the other" - this "external threat" against which Belgians ought to protect themselves. In considering Africans as a group at risk and carriers of the disease, public authorities highlighted the national origin and not the practices as a public health issue. It constituted an entire and sizable population as "a group at risk" in itself and then essentialized it.

\section{Racialization of the Epidemic}

This essentialization led to an immediate racialization of the epidemic, with its deleterious effects. Shortly after the scandal of screening students in April 1987, a strike was called at the Petit Château (Centre for asylum-seekers and foreigners who entered the country illegally) to protest against the discriminatory measures taken by the CPAS (Public Centre for Social Welfare) ${ }^{26}$ against Africans. Indeed, "municipalities did not hesitate to refuse the "Black race" refugees [to join the social assistance] under the pretext that they would all be AIDS carriers" (Le Soir, 24.04.1987). According to Hubert, "many localities identified AIDS with being Black" (1990: 104). Several reports confirmed the exclusion of people for the sole reason that as "Blacks" they would have AIDS. According to Louhenapessy, then and now coordinator of what would become SIREAS (then SidAids-migrants):

The uniqueness also of Belgium, the French Community had the first funded projects for migrants. For years I have felt that I spent an enormous amount of time going to meetings

\footnotetext{
25) Answer of Demeester to the questioning of members of parliament Eerdekens and Winkel, the 7 th April 1987, Annales Parlementaires, Chambre, 1986-1987, Réunion publique de la commission de la santé publique, de la famille et de l'environnement.

26) The CPAS are managed at the local (municipal) level.
} 
and trying to understand. But, at the same time however, it accelerated for us on the ground. Because there, there started to be big problems, legal problems, problems of clear and outright discrimination, of stigmatisation, of racism. Racism and AIDS, the same fight [Racisme et sida, même combat]. We talked like that. It was ... The people would say, 'Yes, but we don't take them because we are afraid that they have AIDS.' There was not yet talk of discrimination. (Interview, 23/07/2009)

There were indeed several scandals here and there in those years, including unfair dismissals, exclusion of HIV-positive African children from schools, and the denial of care. In whatever form, beyond the Zairian cases, public categorization moved to Central Africans and then sub-Saharan Africans. ${ }^{27}$ But, as Louhenapessy stressed it, people were discriminated against due to their skin color, not their nationality, because they were labeled "Black" rather than Belgian, Cameroonian, French, or from the Caribbean. Spontaneous and community-based mobilization (through SIREAS) did not hesitate to denounce these relationships of domination in terms of racism. They later borrowed the vocabulary of discrimination, starting in the 1990s, under the influence of European mobilizations to spread the legal vocabulary, push states to adopt antidiscrimination laws, and protect the rights of patients (Pezeril 2011) including the right to move. ${ }^{28}$ However, again, the policy was built around two seemingly contradictory themes: the creation of an anti-discrimination law and measures to ensure the rights of HIV-positive people on one side, and the closure of borders on the other. Faced with this, patients mobilized, both across Belgium, but also at the European and international levels.

\section{0-2000: Mobilizations of Patients and Control of Their Mobility}

The issue of barriers to the mobility of people living with HIV (PLHIV) appeared on the international scene with the boycott of the HIV Congress in San Francisco in 1990, when militants protested against HIV-related travel restrictions

\footnotetext{
27) "Black Africa" was a quintessentially colonial designation. Public discourse employed the category of "sub-Saharan Africa" with an apparent geographic distinction but functioning on an imagined racial opposition since slavery and colonialism between a Black Sub-Saharan African and a White Maghrebi Africa separated from each other by an impenetrable Sahara.

28) Starting in October 1989, we observed that the European Committee of Ministers recommended "to public health officials to abstain from introducing restrictions on the freedom of movement through ineffective and costly border procedures for all categories of travellers including migrant workers" (Recommendation $\mathrm{n}^{\circ} \mathrm{R}(89) 14$ of 24 October on the ethical implications of HIV infection in the health and social framework).
} 
to the USA. ${ }^{29}$ It became a public issue in the mid-199os, when the changing global configuration of AIDS created a "double scene" (Dozon 2005), with a significant decline in AIDS cases in Western countries, thanks to the availability of effective anti-retroviral treatments, and a continued increase of cases in Africa. In France, according to Mbaye (2009: 45): "It was then that the question of patient mobility began to be considered in political, medical and organisational circles in developed countries," and that the argument of existence of a therapeutic immigration (the idea that people migrate in order to obtain treatment) was articulated alongside the discourse of legitimatizing the fight against immigration.

In Francophone Belgium, the profile of migrants changed beginning in the 1990s, as did the mobilization against AIDS. The Zairian people began to settle and seek refugee status (given the deteriorating situation in the country). ${ }^{30}$ Many found themselves "undocumented" ("sans-papiers"), and HIV-positive people who benefitted from a right of residence on health grounds were not always granted a work permit. In 1998 and 1999, Act up Brussels took up their cause with the relevant ministers and with the media to cancel the orders to evict HIV+ Zairian women (one who was a beneficiary of jus soli in France having only transited via Belgium). ${ }^{31}$

It was during this period that Judith Bisumbu - one of the key African figures $^{32}$ in the fight against AIDS in Belgium, who unfortunately passed away in July 2011 - joined Act Up Brussels. When this latter association disappeared in the early 2000s, Bisumbu took part for a time in Fonds de solidarité sida (AIDS Solidarity Fund), where the money raised would be donated to HIV+ people in greatest need of whom a large part were "those migrants in crisis since they do not have papers, a work permit, are in situations of great difficulty."33 Starting in 2003, she set up an AIDS section in the Projet Matonge, an organization founded by Dr. Marceline Madoki, to promote community health in the

29) Between 1987 and 2011, the US travel ban prevented visits to the US by people with HIV, except in exceptional circumstances (being the spouse or the son of a US citizen or legal permanent resident, for example).

30) See the 2010 report by the Centre for Equal Opportunities and Opposition to Racism, Migrations et populations issues de l'immigration en Belgique.

31) According to an interview with Ariane Guelluy, former member of Act Up, as well as articles published in Le Matin on 05/08/99 and 06/08/99.

32) Born in Burundi, Bisumbu lived for a long time in the DRC before leaving for Gabon, France and coming to Belgium in 1996.

33) The interview with Judith Bisumbu took place in 2006 as part of the research project "VIH et migrations" of the Observatoire du sida et des sexualités (See Dieleman 2008). 
sub-Saharan population. Bisumbu promoted a community-based self-support approach, highlighting her expertise with African women with HIV:

They say all the time that the problem is... that AIDS is much more in the African community. And I think that prevention, the means of prevention there are not suitable. (...) This particular story of AIDS is not subsidized at all. Nobody wants to hear about it. People think that SIREAS and Plate-forme prevention is sufficient. That the others should just go back to where they came from. But I think ... for example, I can learn things from my environment they are quite incapable of knowing! ${ }^{34}$

According to Bisumbu, prevention in African communities must be performed by African leaders, in order to be deemed acceptable and suitable. Given the persistent lack of funding, in 2007 Bisumbu created Echos Séropos d'ici et d'ailleurs (ESDIA), a "resistance blog" to fight HIV stigma, lack of mobilization, and inadequate public campaigns. ESDIA was officially born in 2009 as an association of self-support mainly targeting the sub-Saharan population, "but not exclusively," she says. ${ }^{35}$ In the same vein, in 2005 Dany Kanyeba and Francis Tombolo started Libiki (meaning "hope, salvation, and healing" in Lingala) to not only organize AIDS prevention actions (among hairdressers in Matonge for example), but mostly to listen and give voice to people with HIV. The primary objective for both Kanyeba and Bisumbu (whom Kanyeba considered like her "mom" in the world of AIDS), was to break the silence by coming out with their HIV+ status, and guiding and counselling people with HIV. Though they may have placed the sub-Saharan African communities first among their priorities, they did not want to stop there and remained open to any person requesting information or assistance. However, they were accused of "communitarianism," an accusation brandished at every opportunity, attempting to delegitimize their work and to maintain a hierarchy even if only financial (Manço et al., in this issue). Of note, each of these associations, whether Libiki, ESDIA, or Projet Matonge, relies on volunteer workers on the ground (for HIV prevention and support for people living with HIV). No substantial or sustained support from the State, and specifically the Wallonia-Brussels Federation, has been provided. Bisumbu spoke up again in 2010:

The most glaring, but also the most subtle, perhaps even unconscious (making it difficult to denounce) form of discrimination is that of the associations and organizations dealing with AIDS. At the very least, when faced with inequalities there is a complicity or tolerance [of these organisations] to deprive self-help organizations and people living with HIV of their visibility, representation or of the full recognition that gives weight to our words and our

34) Ibid.

35) See her interview with Fatoumata Sidibé in Amina, n 481, May 2010. 
expertise. Absurd and senseless inequalities that lead us to pay to tell people already paid to listen to us, to gather our experiences sometimes distorting our words along the way. We feel a sort of general tacit will to keep us in a state of perpetual dependency, disability. (Bisumbu in Pezeril, 2010, p. 64-65)

Without official recognition of her work, Bisumbu, like others, had the feeling of being used as much by public officials as by medical or associative actors "meeting the target" (in terms of doctor's appointments for example) by their intermediary and highlighting the "participation" of HIV+ people when it was more of a service or an associative expertise. The situation of these associations and the resentment of their founders are complex issues to analyze. They should also be understood within the context of diminishing funds to support the fight against AIDS and a "sealed envelope" operating approach for more than a decade, fuelling associated tensions. Since the recasting of "promoting health" in 1997, the French Community has financed (though meagrely) ${ }^{36}$ on a regular basis a single association on the ground, SIREAS (becoming Sid'Aids-migrants in 2010) attached to the Immigrant Social Services Office (Service social des étrangers) open to all "migrants." The financial issue does not entirely explain the persistent lack of recognition, contrasting Francophone Belgium in this situation with that of its neighbors, especially the French (in France) who give visibility to the importance of sub-Saharan Africans in the epidemic (starting in 1999 according to epidemiological statistics). ${ }^{37}$ In Belgium, we must recognize that the contrast between the Belgian specialists on the Congo, who have had successful international careers in the field of HIV, and the Congolese professionals, who remain unpaid, is conspicuous.

The numbers however seem clear: while the rate of non-Belgians among new HIV diagnoses has stabilized since 2000 at around $60 \%$, of these, $62.3 \%$ of the cases between 2008 and 2010 were among people from sub-Saharan Africa, of which $19.4 \%$ were from the DRC (equalling 165 diagnoses), $16.8 \%$ from Cameroon, $10 \%$ from Rwanda and Guinea and 6\% from Burundi, according to the latest report from the Scientific Institute of Public Health (Sasse et al., 2011). Also, examining the figures for AIDS cases, cumulative 2006-2010 data yields

\footnotetext{
36) According to the numbers provided by the French Community, a little more than 1.8 million euros were allocated to AIDS prevention programs in 2009, of which about 200,000 euros went to Siréas. The three other thematic associations (see note 20 ) received equivalent financing for their AIDS prevention budgets.

37) Flanders also gives visibility to SAM (Sub-Saharan African Migrants), as they are now called in HIV prevention, since the mid-200os. See the HIV-SAM project of the Institute of Tropical Medicine: http://www.hivsam.be.
} 
a figure of $75 \%$ of Belgian cases from sub-Saharan Africans. ${ }^{38}$ And, looking at mortality rates, HIV/AIDS is the leading cause of death among Bruxellois from sub-Saharan Africa over the period 1998-2007. According to health indicators for the Brussels Region in 2010 "mortality [from HIV] before ages under 75 is 14.5 times higher for men from sub-Saharan Africa than for Belgian men, and 54 times more for women from sub-Saharan Africa than for Belgian women."39 Hard numbers thus contrast sharply with the lack of prioritization of the African public.

Finally, as Delor (1999) ${ }^{40}$ feared, the invisibility of specific publics (by generalizing the risk) only reinforces the discrimination against them, particularly through political action (and its non-recognition of community associations) and handling of statistical knowledge that serves more to identify and locate the carriers of the epidemic than to understand its social and structural causes. (See the illuminating article on this point by Fearnley [2010].) This tendency shows that the shift to a universalist view, which has emancipatory potential, is again tied up with pathways to exclusion. Nevertheless, the sustainability of this invisibility is a Belgian singularity that must be considered in conjunction with the Belgian postcolonial singularity.

\section{Continuity of the Practice of Mandatory Testing: The Other Side of Bio-legitimacy?}

Fassin (2001) showed that the contemporary bio-politic recognized as a higher principle the ethical argument of protecting human life, introducing by then a bio-legitimacy dimension which grants jus soli (right of the soil) to sick people unable to seek treatment abroad. Thus, being ill grants foreigners the right to stay legally in a country. According to Fassin, "Bio-politics of otherness must be understood as an extreme reduction of the social to the biological: the body appears to be the ultimate refuse of a common humanity." In contrast, the 'idea of race' "challenges the notion of a common humanity by differentiating among people at the deepest level of their being, looking for the marks of origins" (2001: 5). It is this tension that we consider in this last section to try to

\footnotetext{
38) This number is not as it appears in the report. It has to be calculated from Table 29 which restates the declared number of AIDS cases by nationality. (Sasse et al. 2011: 36 ).

39) See the Tableau de bord de la santé - Région Bruxelles Capitale, Observatoire de la Santé et du Social, 2010.

40) For whom "AIDS for everyone is no longer AIDS of anyone." (1999)
} 
understand the continuity of the practice of mandatory testing for foreigners attempting to enter and stay in the country.

Indeed, even if it tends to be unofficial, this practice continues. In November 2000, MPs Dallemagne and Van Quickenborne filed a motion for a resolution in the Belgian Senate on "the elimination of the requirement to produce the results of a screening test for AIDS to obtain a Belgian visa, a work or residence permit." ${ }^{11}$ They denounced the continuation of this practice, a practice continued by the diplomatic missions of Brazil, Argentina, Thailand, Congo, and Rwanda - the latter two countries admitting only scholarship students. The MPs pointed out a "confusing and discriminatory situation," "completely useless regarding the spread of the epidemic." They cited the lawyer Carlier (1999) for whom the 1994 judgment of the Court of Justice of the European Communities (later renamed 'Court of Justice of the European Union') - considering that the HIV test performed without the consent of the potential worker, constituted a violation of privacy - "perhaps transposed into a test that would be imposed for crossing borders" (1999: 14). This fundamental protection of privacy should therefore be added to the principles of free movement of persons and non-discrimination. ${ }^{42}$

Eddy Boutmans, Secretary of State for Development Cooperation, stated that the request for an HIV test was "baseless," an "incorrect interpretation of current provisions" and had a lack of clarity in practice. He announced the dispatch of a reverse-instruction to all embassies (Le Soir, 02/12/2000), reiterated by the new Minister of Foreign Affairs in 2007 following a complaint filed with the Centre for Equal Opportunities and Opposition to Racism (Centre pour l'égalité des chances et la lutte contre le racisme). ${ }^{43}$ Despite this, several Congolese migrants interviewed confirmed that, though without any explicit indication, the HIV test remained part of the visa application, and people found to be $\mathrm{HIV}+$ were still being refused visas. ${ }^{44}$

41) Oral examination during the session of $16 / 11 / 2000$. See http://www.senate.be/www/?MIval=/ publications/viewTBlokDoc\&DATUM='11/16/200o'\&TYP=handeen\&VOLGNR=2\&LANG=fr.

42) The anti-discrimination law was voted on in 2003, modified in 2007 in Belgium and included "current and future health conditions" as protected criteria.

43) See the 2008 report Discriminations of the Centre pour l'égalité des chances et la lutte contre le racisme. The resolution, filed on 24 November 2000 , ultimately would never be addressed by the Commission of Foreign Relations (despite its inclusion on the agenda of two sessions in 2001), subsequently rendered null-and-void by the dissolution of the Chambers.

44) Also see Pezeril (2012) and the report on Belgium found in the Guide de référence quant aux réglementations applicables aux déplacements et aux séjours des personnes vivant avec le VIH/sida, a publication of Deutsche AIDS-Hilfe, 2007. 
There is no epidemiological evidence to explain the perpetuation of these barriers to migration, as countries most impacted by HIV are not barred. The first part of the explanation relates to the development of migration policy and its relationship to public health policy. On the one hand, Belgium agrees to regularize immigrants based on their health status. According to the survey on the living conditions of HIV+ people in Belgium (Pezeril 2012), 12.5\% of those with HIV who declare an African nationality are still awaiting regularization. Among $45 \%$ of those with legal permanent residence, $20 \%$ obtained it on the basis of their HIV+ status. Note, however, that the beneficiaries of the right to stay in order to seek treatment are, for the most part, rejected asylum-seekers and, therefore, "victims of increasingly restrictive immigration policies" (Mbaye 2009: 57), which delegitimizes the notion of therapeutic immigration. On the other hand, for immigrants without a residence permit, the cumulative vulnerabilities make their access to treatment difficult and even unlikely despite the implementation of Urgent Medical Assistance in 1996, which admittedly provides reimbursement for prescribed treatments while, at the same time, closes off access to general social welfare (Dieleman 2007).

Moreover, migration policy seems to have hardened once again starting in the mid-20oos, pertaining to the sick, downplaying the impact of biolegitimacy. In 2008, the European Court of Human Rights considered that the expulsion of a Ugandan woman who had developed AIDS did not violate Article 3 of the Convention and was, therefore, not comparable to inhuman and degrading treatment, as therapy was available in her home country. ${ }^{45}$ It implicitly confirmed the practice of the Belgian Immigration Office (Office des étrangers) which only grants asylum or subsidiary protection (since 2006) in cases for which it believes that the "home country has no adequate treatment" (cited by Dieleman 2007: 36). Note that the Court recently condemned Russia for having refused a residence permit to a foreigner because he was HIV positive, stating that it amounted to unlawful discrimination. ${ }^{46}$ Despite pressure from the European States, the Court has limited the radical questioning of biolegitimacy that, after granting a right to stay, would justify expulsion (creating a bio-delegitimization?).

45) The Court does not recognize this argument because "Article 3 does not require contracting States to alleviate such disparities by providing free and unlimited health care to all foreigners who do not have the right to remain in their territories" and that their expulsion does not violate the article in which its application shall be reserved for only very exceptional circumstances. See N. c. United Kingdom, 27 May 2008, nº 26565/05.

46) See Kiyutin c. Russie, March 10, 2011, $\mathrm{n}^{\circ}$ 2700/10. 
The latter may explain, in our view, the perpetuation of barriers to mobility and is grounded in the colonial and imperial history and in the memorial weight of this story. The fear of "Zairian AIDS," as it has been built in the Belgian imagination, helped legitimize, officially for a time, the closing of borders, at least for those whom the State subsidized their stay. This closure does not operate according to the same logic based on the country of origin of migrants. If in the beginning the Congo was the only country targeted by the screening policy, this latter policy gradually extended to other African countries and the "South." Thus, the influence of the colonial historicity fits and feeds the racial question and therefore goes beyond Belgo-Congolese relations. As summarized by Thevenin (2002), "The affirmation of an irreducible African otherness logically enriches the calls to put into place a cordon sanitaire tested in many other Western countries, the requirement of an HIV test prior to entry into the territory."

Finally, it appears that the bio-legitimacy is effective in European territories as it provides access to regularization. But firstly, it is tempered by the fact that it no longer prevents the removal of sick foreigners (if they can have official access to treatment in their country) and secondly, it does not operate in migrants' countries of origin or not through the same basis. As the "therapeutic citizenship" in Africa differentiates "those who should live from those who could go without treatment" (Nguyen 2010), through medical triage technology, in Europe, it decides whether the migrant can have the right to stay legally or not, through an administrative triage. It is not insignificant that testing is performed by the Belgian officials outside Belgian borders while the rights of HIV+ people are guaranteed in the country, as if the restriction over there would allow a humanitarian policy here and vice versa.

\section{Conclusion}

The analysis of the political management of the AIDS epidemic in relation to African migrants can only be understood in connection with migration policy and that of non-discrimination. In this sense, Francophone Belgium is part of a global dynamic, which acts mainly at the European level, while strongly influenced by the international context. ${ }^{47}$ We should not ignore the uniqueness

\footnotetext{
47) According to the Guide de Référence: réglementations applicables aux déplacements et aux séjours des personnes vivant avec le VIH/Sida, in 2010, 10 or so countries still categorically refuse admission to people with HIV: the Bahamas, Brunei, Equatorial Guinea, Iraq, Jordan, South Korea, North Korea, Namibia, Papua New Guinea, Qatar, Russia, Singapore, the Salomon Islands,
} 
of the Francophone Belgian case, which is understood in light of a postcolonial perspective. Finally, from a theoretical point of view, we believe that the concept of "colonial debris," as developed by Hunt (2008) and Stoler (2008), is relevant and accounts for the current dynamics. The notion of debris emphasizes ambiguities produced by imperial formations (another heuristic concept of Stoler) and elusive vectors of responsibility and does not presuppose either a measurable legacy or identifiable contributors, as in the concept of 'colonial legacies.' We must accept an uncertain, unfinished, and ambiguous history, which can also be written as allusions, evasive connections, and even as unexplainable. Indeed, the continuation of mandatory screening in spite of the official commitments of the State and the associative mobilizations in Belgium remains partially inexplicable (at least without actually observing current practices within the Belgian Embassy in Kinshasa). In addition, this debris is probably more imperial than strictly colonial because it far exceeds the BelgoCongolese relationships alone and is part of the "racialized relationships of allocations and appropriations" that formed imperialism (Stoler 2008: 193). Moreover, the notion of debris allows us to highlight the capacity for action and resistance - measures implemented to divert this racialization - whereas the actors do not possess the ability to accept or reject the colonial legacy; they can only cope with its debris. Hunt showed convincingly how the essentializing of the Other in the colonial framework legitimized sexual violence (especially the invisibility of gendered violence) and how it continues to affect the relationships between Belgians and Congolese, particularly pervasive in the Congolese territory (in the context of the war at its borders). Using the same logic, the "Zairian AIDS" imaginary took root in the exaltation of sexual difference, before the State tried to passively intervene in rendering invisible the sick Africans in the public arena. However, this ultimately led to a lack of prioritization of the public ${ }^{48}$ and non-recognition of the so-called community associations. Difficulties in access to treatment (and reimbursement) and the entry restrictions of HIV+ people to the Belgian territory, especially among Congolese and Belgian-funded scholarship seekers, still exist today. If the disease had been first racialized now, after the shift to a universalist discourse, associations that focus on Sub-Saharans Africans are denied support.

Sri Lanka, Sudan, Suriname, the United Arab Emirates, and Yemen. The United States lifted the ban on permanent residence that same year.

48) Not until the recent BREACH symposium, organized at the end of 2012, which brought together all of the actors in the fight against AIDS in Belgium, were two priority populations men having sex with men and migrants from Sub-Saharan African - placed, for the first time, at the forefront of the discussion, under Flemish pressure. 
Thereby, it is the well-known paradox of equality and difference that accounts for the fact that treating everybody equally can be unjust at times. The very ambiguous public invisibility was explained by the desire not to stigmatize a population nor build a "Republican virus" within the French-speaking community. However, the result, as Delor (1999) feared, is a lack of recognition of the actors working on behalf of this public leading to a lack of concrete action while failing to address the racialization of the epidemic. In this sense, the tension measured by Fassin at the heart of bio-politics, "between the supreme universality of life and the exaltation of difference" (2001), is more important than ever but unfortunately tends to favor the dynamics of racialization over that of bio-legitimacy. In a European context where the "crisis" is constant and where xenophobic parties are normalized, immigrants, including those who are sick (and therefore are seen as "costly") are the perfect scapegoats. The recent decision in Antwerp to no longer systematically reimburse the anti-retroviral treatment of undocumented immigrants (sans-papiers) does not foretell a reassuring future. ${ }^{49}$ As Dozon stated, "the epidemic fits strongly within the meaning of domination and dependence that have long marked the African people and continue to largely occupy the land of their recent post-colonial history" (2005: 216). Hence, it is time for stakeholders involved in Belgium to further question this postcolonial debris, lest they continue to recreate them, sometimes even unknowingly.

\section{References}

Bancel N., F. Bergnault, P. Blanchard, A. Boubeker, A. Mbembe and F. Vergès (eds.) 2010. Ruptures postcoloniales, Les nouveaux visages de la société française. Paris: La Découverte.

Bayart, J-F. 2009. Les études postcoloniales, une invention politique de la tradition? Sociétés politiques comparées, 14: 1-46. Translated in English in Public Culture, 23 (1), Winter 2011.

Bibeau, G. 1991. L'Afrique, terre imaginaire du sida. La subversion du discours scientifique par le jeu des fantasmes. Anthropologie et Sociétés, 15 (2-3): 125-147.

Cahen, M. 2011. À propos d'un débat contemporain: du postcolonial et du post-colonial. Revue historique, 66o (4): 899-913.

49) The President of CPAS (Belgium's Public Centre for Social Welfare) in Antwerp, Mrs. Homans of the N-VA (the Flemish separatist party, Nieuw-Vlaamse Alliantie) stated: "We are going to evaluate each HIV+ person's application on a case by cases basis to determine if they are eligible to receive an antiretroviral treatment in their home country. If this is the case, we don't see any reason why the CPAS of Antwerp ought to assume the responsibility of the costly antiretroviral drugs." De Redactie, 18/02/2013, personal translation. 
Cantelli, F. 2007. L'Etat à tâtons. Pragmatique de l'action publique face au sida. Bruxelles: P.I.E. Peter Lang.

Carlier, J-Y. 1999. La libre circulation des personnes vivant avec le VIH/sida. Luxembourg: Office des publications des Communautés Européennes.

Cervera, M. \& Hourcade, R. 2010. L'épiderme et l'épidémie. Emulations, 8: https://sites.google .com/a/revue-emulations.net/www/archives/n8/epiderme.

Clatts, M. C. \& Mutchler, K., 1989. AIDS and the dangerous other: Metaphors of sex and deviance in the representation of disease. Medical Anthropology, 10(2-3): 105-114.

Clumek N., Mascart-Lemone F., De Maubeuge J., Brenez D. \& Marcelis L. 1983. Acquired immune deficiency syndrome in Black Africans. The Lancet. March 19;1 (8325):642.

Delor, F. 1999. Les nouveaux défis de la prévention sida. Bruxelles: unpublished.

Demart, S. 2013. Histoire orale à Matonge (Bruxelles): un miroir postcolonial. Revue Européenne des Migrations Internationales, 1 , forthcoming.

Dieleman, M. 2008. Migrant-es subsaharien-nes et VIH. Trajectoires et vulnérabilités. Bruxelles: Observatoire du sida et des sexualités.

Dieleman, M. \& Pezeril, C. 2010. Les difficultés à concilier VIH, migration et vie professionnelle. Echos Séropos d'ici et d'ailleurs, Septembre: $28-30$.

Dodier, N. 2003. Leçons politiques de l'épidémie de sida. Paris: Editions de l'EHESS.

Dozon, J-P. \& Fassin, D. 1989. Raisons épidémiologiques et raisons d'Etat. Les enjeux sociopolitiques du SIDA en Afrique. Sciences Sociales et Santé, VII (1): 21-36.

Dozon, J-P. 2005. De l'intolérable et du tolérable dans l'épidémie de sida. Un parallèle entre l'Occident et l'Afrique. In: Bourdelais \& Fassin (dir). Les constructions de l'intolérable. Paris: La Découverte: 197-224.

Farmer, P. 1996. SIDA en Haïti: la victime accusée. Paris: Karthala.

Fassin, D. 1994. Le domaine privé de la santé publique. Pouvoir, politique et sida au Congo. Annales. Histoire, Sciences Sociales, 49 (4): 745-775.

_ 1999. L'indicible et l'impensé : la "question immigrée" dans les politiques du sida. Sciences sociales et Santé, 17 (4): 6-34.

- 2001. The biopolitics of otherness. Anthropology Today, 17 (1): 3-7.

Fearnley, L. 2010. Epidemic Intelligence. Langmuir and the Birth of Disease Surveillance. Behemoth. A Journal on Civilisation. 3 (December): $36-56$.

Gillet, F. 2007. Contrepoint. L'histoire coloniale en débat: examen d'une Belgique en repentir. Mouvements, 51 (3): 70-77.

Gilman, S. L. 1988. Aids and Syphilis: the Iconography of Disease. In: D. Crimp (éd.), Aids: Cultural Analysis-Cultural Activism, Cambridge, Mass., MIT Press, pp. 87-107.

Hooper, E. 1999 The River. A Journey to the Source of HIV and AIDS. Boston: Little Brown and Company.

Hubert, M. 1990. AIDS in Belgium: Africa in Microcosm. In: Misztal \& Moss (eds.). Action on Aids. National Policies in Comparative Perspective. NY/Westport/London: Greenwood Press: 101-119.

Hunsmann, M. 2010. Les relations sexuelles simultanées comme moteur du VIH en Afrique sub-saharienne: la fin d'une idée reçue?. Transcriptases, 144 (Octobre): 55-58.

Hunt, N. 2008. An acoustic register, tenacious images, and Congolese scenes of rape and repetition. Cultural Anthropology. 23 (2): 220-253.

Jacobs, D. \& Réa, A. 2005. Construction et importation des classements ethniques. Revue Européenne des migrations internationales. 21 (2): 35-59. 
Jacquemin, J-P. 2004. Les Congolais dans la Belgique impériale. In: Bancel et al. Zoos humains. Paris: La Découverte: $253^{-258}$.

Kagné, B. 200o. Africains de Belgique: de l'indigène à l'immigré. Hommes et Migrations 1228 (Novembre-Décembre): 62-67.

Kagné, B. \& Martiniello, M. 2001. L'immigration d'origine subsaharienne en Belgique. Courrier Hebdomadaire du CRISP, 1721.

Mbaye, E. M. 2009. Sida et immigration thérapeutique en France: mythes et réalités. Sciences Sociales et Santé, $27(1): 43-62$.

Mbembe, A. 2006. (entretien) Qu'est-ce que la pensée postcoloniale? Esprit, Décembre: 117-133.

Musso, S. 2009. La mesure des "migrants" dans les statistiques du sida en France. Bulletin AMADES, 77 .

Nkuku Khondé C. 2006. L'histoire du sida au Congo selon les sources orales. In: Denis P. \& Becker C. (dir). L'épidémie du Sida en Afrique subsaharienne: regards historiens. Louvain-La-Neuve/ Paris: Bruylant/Academia/Karthala.

Nguyen, V-K. 2010. The republic of therapy: triage and sovereignty in West Africa's time of AIDS. Durham, NC: Duke University Press.

Pezeril, C. (dir). 2010. Emploi et VIH. Maintien, retour et non discrimination dans l'emploi des personnes vivant avec le VIH en Belgique. Bruxelles: Observatoire du sida et des sexualités.

— . 2011. Paradoxe de la lutte contre les discriminations: la question de la visibilité des personnes séropositives. Sociologie Pratique, 23 (2): 31-44.

—. 2012. Premiers résultats de l'enquête "Les conditions de vie des personnes séropositives en Belgique francophone (Wallonie et Bruxelles)". Bruxelles: Observatoire du sida et des sexualités/ Plate-forme Prévention Sida/ CES (U-SL).

Piot P. et al. 1984. Acquired immune deficiency syndrome in a heterosexual population in Zaire. The Lancet. July 14; 324 (8394): 65-69.

Roitman, J. 2011. Guest Editor's Letter. Public Culture, 23(1): 1-18.

Sasse, A., Verbrugge R., Van Beckhoven D. 2011. Epidémiologie du sida et de l'infection à VIH en Belgique - Situation au 31 décembre 2010. Bruxelles: Institut Scientifique de Santé Publique.

Stoler, A. L. 2008. Imperial Debris: Reflections on Ruins and Ruination. Cultural Anthropology, 23 (2): 191-219.

Thévenin, M. 2002. Africains, sauvageons du sida. Vacarme, 19 (Printemps): http://www.vacarme .org/article272.html.

Vangroenweghe, D. 2000. Sida et sexualité en Afrique, EPO: Bruxelles.

Vincineau, M (dir). 1991. Le sida: un défi aux droits. Bruxelles: Bruylant. 